\title{
路面電車を考慮した都市交通における信号方式に関する研究*
}

\section{A Study on the Traffic Signal Strategy in City Traffic Consideration of Streetcar *}

松本 修一** 熊谷 靖彦*** 川嶋 弘尚****

By Shuichi MATSUMOTO $* *$ Y Yasuhiko KUMAGAI*** Hironao KAWASHIMA****

\section{1. はじめに}

様々な交通機関の混在する今日の社会において, 都市交通における交通渋滞，およびそれに伴う環境 問題の影響は大きい。 その緩和策として自動車を対 象としたTDM (Transportation Demand Manageme $n t ）$ が，近年わが国でも注目されるようになってき た.

このような社会状況のなか過度な自動車依存によ る弊害が問題視され，バス，地下鉄，路面電車など 都市内公共交通機関の荷う役割が見直されてきてい る. 公共交通機関は, 自動車交通に比べると環境負 荷の少なく, 輸送能力の高い交通機関であると言わ れている，1)その中で路面電車は，路上の空間を占 有するため限られた都市内の道路交通容量に制約を 加え, 自動車交通に大きな影響を与えている.また 自動車の交通混雑により路面電車の定時性の確保が 困難であるという問題がある．このような背景から 現在では公共交通と自動車交通を融合させた交通施 策が必要とされている.

公共交通と自動車交通を融合させた交通施策とし てはPTPSなどバスを対象としたものが主流であり， 路面電車に対する施策は余り行われていない. 更に は路面電車の表定速度は年々減少している. またこ の結果として路面電車が時間通り電停に来ないとい う問題も生じている.このような点から路面電車に 対する速度低下を防ぐ交通施策が必要とされている. そこで本研究では, 路面電車に対する施策として路 面電車優先信号方式の導入を提案し，それによる路 *キーワーズ：L R T, 都市環境評価, 信号制御方式 **学生会員, 工修, 慶應義塾大学大学院理工学研究科 $* * *$ 正会員,学博,高知工科大学総合研究所 (高知県香美 郡土佐山田町宮の口)

****正会員, 工博, 慶應義塾大学理工学部管理工学科 （神奈川県横浜市港北区日吉3-14-1, TE

L:045-563-1141, FAX045-566-1617)
面電車および自動車の交通流, 排出ガス量の変化に ついて検討し, その効果を比較する.

\section{2. 既往研究のレビュー}

都市交通において路面電車や L R T 考慮した既 往研究としては，大きく 3 つに分かれる. 1 つめは L R T 導入時の交通状況の変化をケーススタディー として研究したもので, ミクロ交通シミュレーショ ンモデルVISITOKを用いLRT (Light Rail Trans i t ）導入計画における導入効果の推定および自動車 交通への影響の評価を行った森津らの研究 ${ }^{2)}, \mathrm{L} \mathrm{R}$ T導入時, 整備時のL CA（Life Cycle Assessmen t）を適応した環境評価, 便益分析などを行った中 川らの研究3) 5)などがある. 2 つめとしては, L R Tを導入する場合（またはした場合）の意識調查と してS P 調査を用いた森本らの研究6), ヒアリング 調査を行った田尻の研究 ${ }^{7)}$, 中野らの研究 ${ }^{8)}$ などが ある. 最後に電車優先信号の評価に関する研究であ る. 水間ら ${ }^{9)}$ はスルーバンドマッチング法の有用性 を示唆した。また路面電車優先信号方式の導入実態 を考察したもの ${ }^{10)}$ な゙゙がある.

本研究は, ミクロシミュレータを用い路面電車優 先信号導入効果を提案・評価するものであり， 3 番 目の研究にあたるが, 自動車, 路面電車などの現地 での実データを詳細に用いた点, 路面電車優先信号 方式を検討する際に実務面でも有用な研究である.

\section{3. 本研究の概要}

本研究では路面電車の定時性および速達性確保の 観点から, 広島市紙屋町交差点において路面電車を 優先した信号方式を提案する. また現行の信号方式 と提案する信号方式での自動車の旅行時間, 停止回 数, 路面電車の定時性, 速達性などの改善効果を比 較する.これらの研究フローを図 1 として示す. 


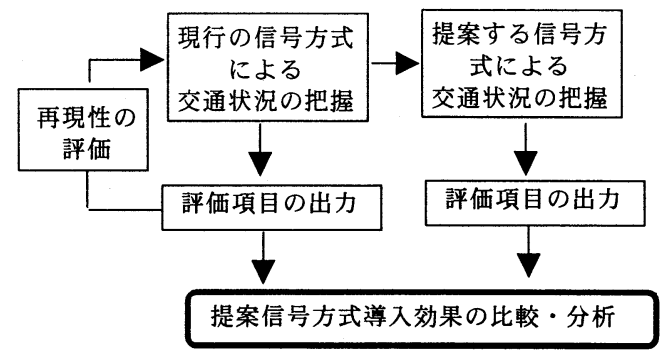

図-1 本研究のフロー

\section{4. モデルの概要}

\section{（1）路面電車の走行モデル}

既往の研究では, 路面電車を 1 種類の車種として 扱ったものが多い。しかし広島における路面電車は 1 両編成の電車（以下単車と記す），2３両編成 の電車（以下連接車と記す）, L R T であるグリー ンムーバ (以下 GM と記す) の 3 種類が走行してい る.これら路面電車の車両長の違いによる交差点で 右左折を行う際の直進自動車の滞留, 信号や電停で の運行障害が発生している. 本研究ではそれらの違 いを考慮した路面電車の車両モデルを作成する．表 1 として, 路面電車の車両モデルとして設定した路 面電車の車両長, 最大速度, 最大加速度, 最大減速 度の諸元をまとめる.

\begin{tabular}{|c|c|c|c|}
\hline & \multicolumn{3}{|c|}{ 路面電車の諸元 } \\
\hline & 車両長 (m) & $\begin{array}{l}\text { 速度 } \\
(\mathrm{km} / \mathrm{h})\end{array}$ & $\begin{array}{l}\text { 加速度および } \\
\text { 減速度 }\left(\mathrm{km} / \mathrm{s}^{2}\right)\end{array}$ \\
\hline 単車 & $12 \sim 13$ & $35 \sim 40$ & 2.5 \\
\hline 連接車 & $25 \sim 27$ & 40 & 3 \\
\hline GM & 30 & 40 & 3.5 \\
\hline
\end{tabular}

\section{（2）路面電車の乗降モデル}

路面電車は, 電停に到着すると乗車客を乗車させ, 目的地の電停に到着すると降車させる.このために 電停で停止する時間は乗降客によって大きく異なる. またこの時間は路面電車の車種によっても大きく異 なることが考えられる.この停止時間を調査し, 乗 降時間と乗降客数, 車種に関する違いを算出した. 調查は平成 15 年 10 月 30 日〜 11 月 1 日にかけ て広島電鉄本線の胡町電停および八丁堀電停におい て 7 時〜 11 時の間乗降口に対しビデオで撮影する
方法を用いた．ここで単車，連接車はいずれも乗降 ロにステップがあるが, GMはノンステップ車両で ある. また乗降口の幅は単車, 連接車は $0.85 \sim 1.2 \mathrm{~m}$ GMは1.3mである.これら乗降客と乗降時間の関係 を図 $2 ， 3$ に示す．これから式 $1 ， 2$ のような線形 回帰式を求める.

$$
\begin{aligned}
& T_{o n}=\alpha N_{o n}+\beta \\
& T_{o f f}=\alpha^{\prime} N_{o f f}+\beta^{\prime}
\end{aligned}
$$

$$
\text { ここに } \alpha, \beta, \alpha^{\prime}, \beta^{\prime} \text { はパラメータ, } T_{o n} \text { は乗車 }
$$

時間, $T_{o f f}$ は降車時間, $N_{o n}$ は乗車人数, $N_{o f f}$ は降 車人数と定義する.これらの車種別パラメータおよ びその際の重相関係数, 優位水準 $95 \%$ での F 值を 表 2,3 にまとめる.

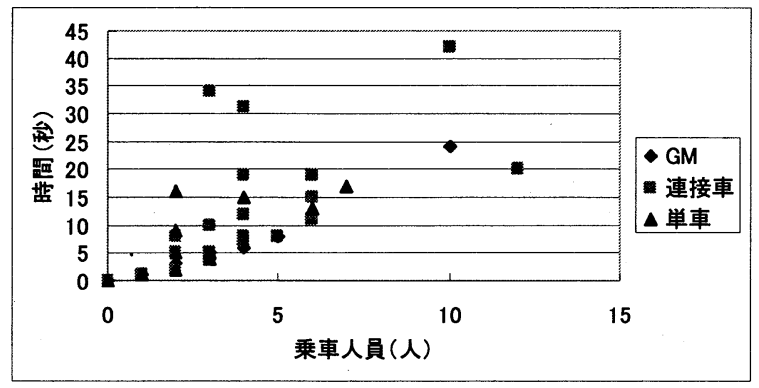

図-2 乗車人数と乗車時間の関係

\begin{tabular}{|c|c|c|c|c|}
\multicolumn{1}{c}{} & \multicolumn{3}{c}{ 表 2} & \multicolumn{3}{c|}{ パラメータの推定結果 } \\
\cline { 2 - 5 } \multicolumn{1}{c|}{} & $\alpha$ & $\beta$ & 重相関係数 & F 值 \\
\hline 単車 & 2.04 & 0 & 0.94 & 0.12 \\
\hline 連接車 & 2.83 & 0.03 & 0.59 & 0.07 \\
\hline $\mathrm{GM}$ & 2.51 & 0 & 0.75 & 0.19 \\
\hline
\end{tabular}

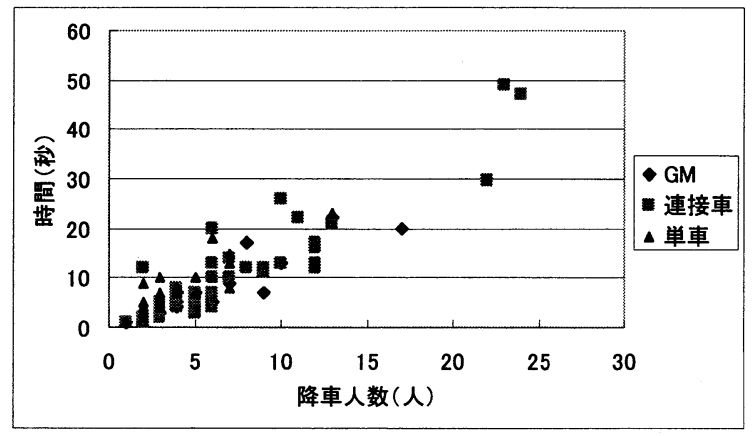

図一 3 降車人数之降車時間の関係 
表ー 3 パラメータの推定結果

\begin{tabular}{|c|c|c|c|c|}
\cline { 2 - 5 } \multicolumn{1}{c|}{} & $\alpha^{\prime}$ & $\beta^{\prime}$ & 重相関係数 & $\mathrm{F}$ 值 \\
\hline 単車 & 1.83 & 0.2 & 0.82 & 0.24 \\
\hline 連接車 & 1.32 & 0 & 0.84 & 0.26 \\
\hline $\mathrm{GM}$ & 1.63 & 0 & 0.81 & 0.44 \\
\hline
\end{tabular}

表 2 において, 連接車乗車時のモデルの重相関係 数が他の車両と比べて小さい值を示した.この原因 としては車両の編成数にばらつきがあることが考え られるが, 最も乗車人数と乗車時間の関係に影響す る要因は車内混雑状況である. 本調查場所における 連接車の運行時間は多くの乗客を輸送するため, 主 にラッシュ時間帯にあたる. ラッシュ時における連 接車両の車内が込んでいるため少ない人数で乗車時 間が長くなる車両が発生した。 その結果乗車時間に ばらつきが生じ重相関係数が低くなった.

（3）シミュレーションモデルと使用データ

本研究では, ドイツPTV社の交通ミクロシミュレ ータVISSIM ${ }^{11)}$ を用いて, シミュレーション実験を 行った. VISSIMでは, 車両の発進挙動や前車への 追従挙動などのミクロな挙動を, WIDEMANNの交 通心理状況を考慮したモデル12)を用いている．次に 車両に関しては1台づつ車両長, 幅, 加速度等を設 定できる．また自動車以外にも人や電車などの車両 長，速度などを設定することが可能である．更に交 通感応制御プログラムVAPを利用することによって， 複雑な信号制御も比較的簡単に構築することができ る.以上のことから，VISSIMは本研究に適した交 通シミュレータだと言える。 ${ }^{13)}$ また路面電車に関し ては，表 1 にある車両とし，道路中央の専用軌道を 通行するように設定した.

また本研究では, 広島市内の路面電車軌道の中で 最も自動車交通量が多く, 信号での路面電車の待ち 時間が最も多い区間である図 4 を対象とした。この 研究対象において図 5 のネットワークを作成した. ネットワークはリンク 102 本, ノード 34 個, セ ントロイド 12 個で構成される.この地域の平成 1 5 年 11 月 19 日 9 時〜 11 時における 42 简所の 車両感知器データをもとにセントロイドから流入交 通量を 5 分毎に, ネットワーク上の 8 つの交差点で
の分岐率を 5 分毎に設定した. また流出入交通量の 観測点を 7 箇所設定した. 次に信号周期, オフセッ ト，スプリットなどの信号制御ロジックは実際に同 時刻，同場所における信号制御データを用いた系統 だった信号制御である. また路面電車の走行ルート， 時刻表は路面電車運営主体の資料をもとに作成した. 路面電車通過時刻および路面電車の車種は現地にお いて実測したデータを用いた. 図 6 として紙屋町周 辺の電停配置および旅行時間の検討方向を示す. 各 電停における乗客の乗降人数は対象路線の約 $40 \%$ の車両において実測した 9 時〜 12 時台の乗降客調 查データ ${ }^{14)}$ を用いた.

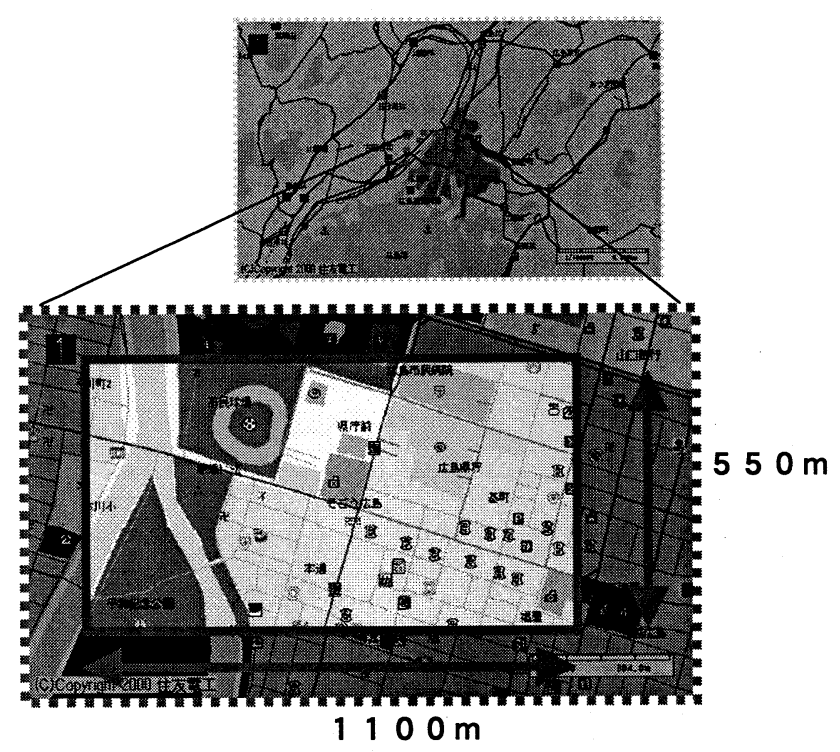

図-4 対象地域

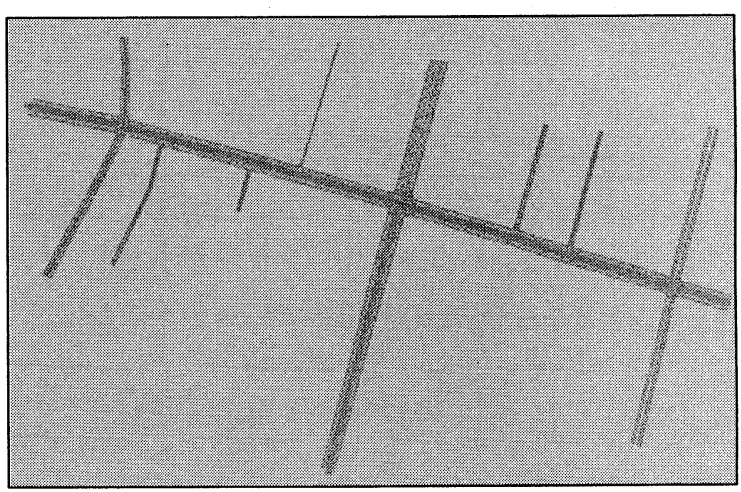

図ー5 作成ネットワーク 


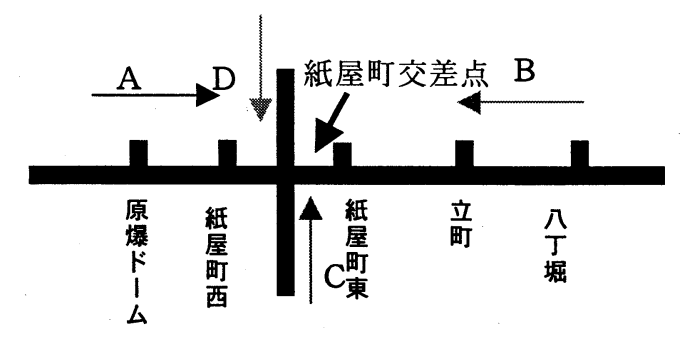

図－6電停の配置および旅行時間検討方向

次に自動車の排出量算出に関しては東京都環境保 全局が作成した NOxおよび $\mathrm{CO}_{2}$ の推計式を用い た. ${ }^{15)}$ 本研究では大型車, 小型車の区別なく全車両 のトリップごとの旅行速度を追従モデルを用いて算 出し, その平均值を車種ごとに時間単位で集計した. 次に各時間帯での平均旅行速度の結果からネットワ 一ク内での排出ガス量の評価を行った. ${ }^{16), 17)}$

\section{5. 再現性の評価}

本研究では実際の交通状況との再現性の評価のた めに, 路面電車の旅行時間および電停への到着時刻, 自動車の断面交通量を比較する.なお本研究では違 法駐車車両や停止中のタクシーに関しては考慮して いない.

\section{（1）路面電車の旅行時間}

原爆ドームー八丁堀間のシミュレーション上での 10 時台における各電停の原爆ドーム前電停を起点 とした上りおよび八丁堀電停を起点とした下りの路 面電車の平均旅行時間と実際の時刻表から算出され る所要時間, および実測にて得た平成 16 年 1 月 2 3 日の路面電車の旅行時間を比較する.

この結果を図 7,8 として示す. なおピーク時で の路面電車優先信号の導入に関して検討したが, 本 研究地域ではピーク時の路面電車の運行間隔が 1 分 以下であり, 優先信号の導入によって南北の車両の 通行が非常に困難であったため, オフピーク時の 1 0 時台とした.

シミュレーション上での上りの路面電車の平均旅 行時間は 378 秒, 実測值は 411 秒となり, 上り のシミュレーション值は実測値より $8.05 \%$ 短い結果

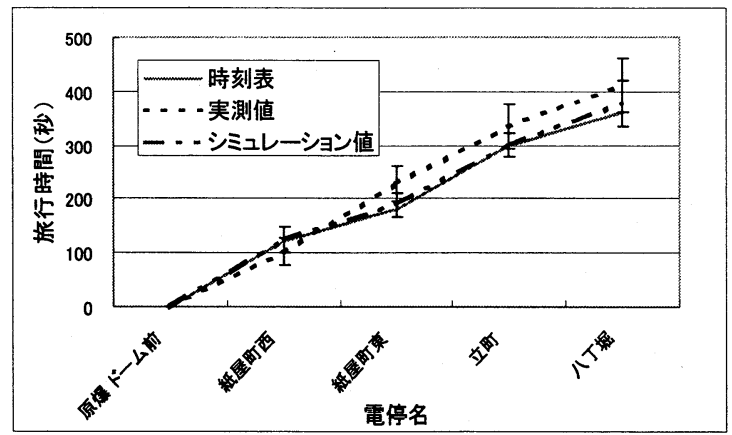

図-7 上りの旅行時間

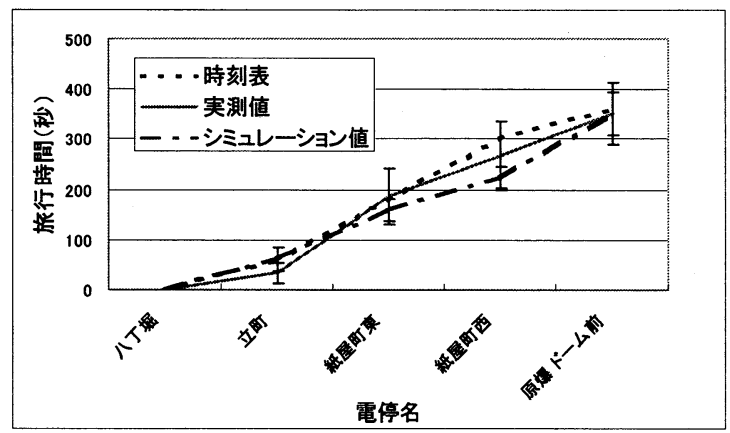

図-8 下りの旅行時間

となった. またこの区間での路面電車の時刻表から の算出される所要時間は 360 秒である.

一方下りではシミュレーション上での路面電車の 平均旅行時間は 35.0 秒, 実測值は 351 秒となっ た.この区間での路面電車の時刻表からの算出され る所要時間は 360 秒であり, 下りの実測の旅行時 間は時刻表から算出される所要時間より 9 秒短い結 果となった.これらから原爆ドーム前電停から八丁 堀電停間での旅行時間に関しては実際の路面電車と ほぼ同様の結果となったことが分かる.

次に紙屋町東および西電停の上り, 下りにおける 各路面電車が到着した時間を実測値とシミュレーシ ヨンで再現したシミュレーション值とで比較した. この到着時間の差を表 4 としてまとめる.

\begin{tabular}{|c|c|c|c|c|}
\multicolumn{2}{c|}{ 表 4 到着時間の差 (単位 : 秒) } \\
\cline { 2 - 5 } \multicolumn{1}{c|}{} & 紙屋町交差点西電停 & \multicolumn{2}{c|}{ 紙屋町交差点東電停 } \\
\cline { 2 - 5 } & 上り & 下り & 上り & 下り \\
\hline 平均 & 19.28 & 15.87 & 19.12 & 20.93 \\
\hline 標準偏差 & 19.38 & 14.03 & 16.12 & 20.54 \\
\hline 最大誤差 & 37.30 & 30.70 & 37.20 & 58.50 \\
\hline 最少誤差 & 5.40 & 5.80 & 1.50 & 0.10 \\
\hline
\end{tabular}

この結果, 実測值とシミュレーション值との誤差 
の平均はおおよそ 20 秒以内におさまった。これら 到着時間のシミュレーション值を横軸に, 実測值を 縦軸にプロットした結果を図 9 として示す.

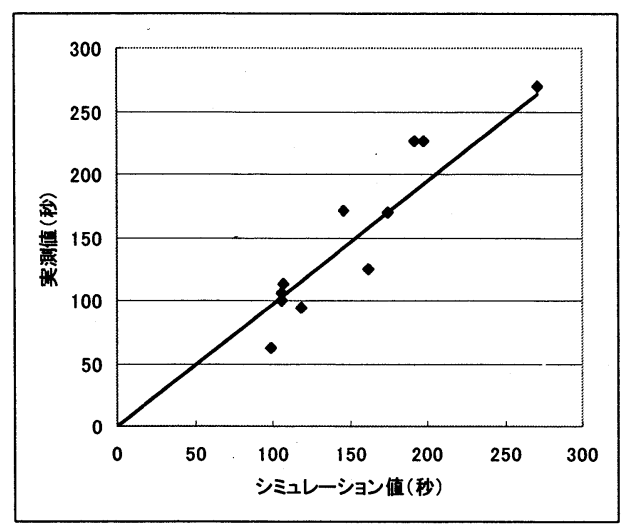

図 - 9 到着時間の比較

この回帰式は, $y=0.97 x$ （重相関係数 $0.83, \mathrm{t}$ 值 8.49）となった.これらの結果から本研究での路 面電車の挙動は高い精度で再現できたと言える.

\section{（2）自動車の断面交通量}

自動車交通量の評価は, 渋滞長や旅行時間計測が 出来なかったため, 図 10 の 7 箇所における 5 分間 交通量の感知器交通量データと再現交通量の相関係 数, 平均誤差率によって評価した. この結果各断面 での相関係数の平均が 0.87 , 平均誤差率 $6.9 \%$ となっ た.これは同時刻の交通状況を再現するのに十分な 結果であると言える.

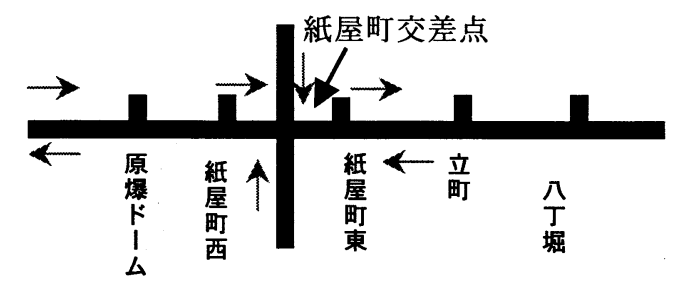

図-10 自動車断面交通量の比較場所

\section{6. 信号方式導入効果の比較}

\section{（1）提案信号方式}

本節では, 提案する信号方式のアルゴリズムにつ いて説明する. まず路面電車と信号および車両感知 器の位置関係を図 11 として示す.

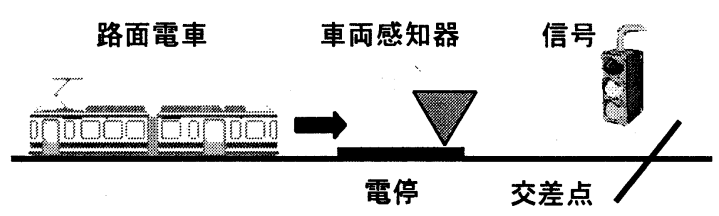

図-11 信号と感知器の位置関係

図 11 にあるように, 路面電車進行方向が交差点 に向う電停上に車両感知器を設ける. 路面電車が電 停を発車し感知器を通過する際に交差点にある信号 の状態に応じて信号の現示を変更するという設定と した.

次に提案信号方式として，「路面電車優先信号方 式」（以下優先信号方式と記す）および「路面電車 準優先信号方式」（以下準優先信号方式と記す）の 2 種類の方法について図 $12 ， 13$ に示す.ここで は A, B，Cの各方向から路面電車が流入するが路 面電車の速達性を重視するために, 信号提示の優先 順位を路面電車の通行台数が多い順に A, B , C と した.

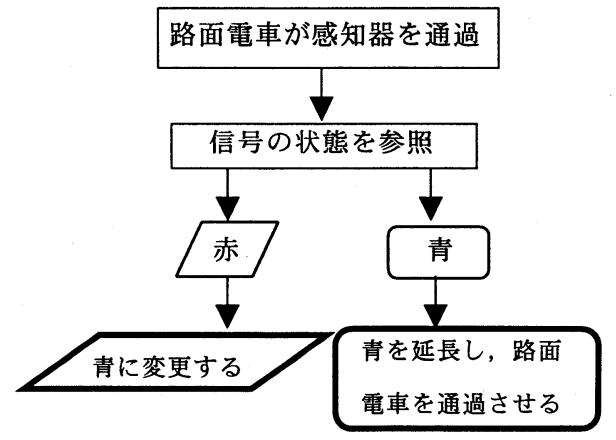

\section{図-12 路面電車優先信号方式}

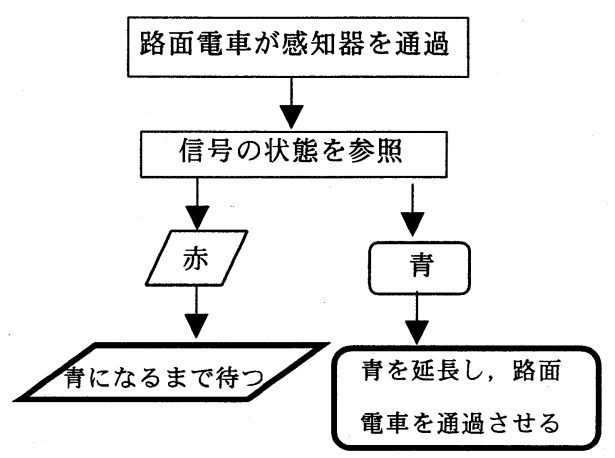

図-13 路面電車準優先信号方式

\section{(2) 計算結果}

1 節にて説明した信号方式にてシミュレーション を行った結果と 5 章でのシミュレーション結果を比 
較し，その効果を路面電車の速達性，定時性と自動 車の旅行時間などの変化で比較する.

\section{(a) 旅行時間の評価}

図 6 で定義した方向別での自動車と路面電車の旅 行時間を比較した結果を表 5 として示す.

\section{表 -5 旅行時間の比較}

\begin{tabular}{|c|c|c|c|c|c|c|}
\hline 車種 & \multicolumn{2}{|c|}{ 路面電車 } & \multicolumn{4}{|c|}{ 自動車 } \\
\hline \hline 方向 & $\mathrm{A}$ & $\mathrm{B}$ & $\mathrm{A}$ & $\mathrm{B}$ & $\mathrm{C}$ & $\mathrm{D}$ \\
\hline 現行(秒) & 412.47 & 350.53 & 737.82 & 1088.97 & 274.37 & 129.45 \\
\hline 準優先信号 & $21.28 \%$ & $7.80 \%$ & $41.19 \%$ & $6.99 \%$ & $-8.43 \%$ & $-52.89 \%$ \\
\hline 優先信号 & $54.20 \%$ & $40.12 \%$ & $62.13 \%$ & $25.06 \%$ & $-94.30 \%$ & $-193.55 \%$ \\
\hline
\end{tabular}

$\mathrm{A}$ 方向で遅れ時間の改善が，D方向で遅れ時間の悪 化が顕著であることが分かる．また表 7 から準優先 信号方式においては，遅れ時間，停止時間，停止回 数がすべて改善されており，準優先信号方式におけ る自動車の混雑はネットワーク全体として考えると 改善されることが分かる．反対に優先信号方式では， 遅れ時間, 停止時間, 停止回数がすべて悪化 しており，自動車の混雑を悪化させることが 分かる. 以上のことから，準優先信号方式が 路面電車および自動車の交通状況を改善する 信号方式である.

\section{（b）定時性の評価}

表 5 から路面電車の旅行時間は準優先信号方式お よび優先信号方式においてともに改善されることが 分かる.このことから本研究で提案した信号方式は 路面電車の速達性の確保に有効な方式であることが 分かる.さらにA方向, B方向では青時間長が長く なるため自動車の旅行時間も改善される。一方で C 方向，D方向は赤時間長が長くなるため自動車の通 行に支障をきたし，交通混雑を引き起こすことが分 かる.

ここで信号方式の変更による紙屋町交差点での自 動車の待ち時間などの変化に着目し, これらの信号 方式の自動車への影響を評価する. 表 6 として図 6 で定義した各方向での自動車の遅れ時間の変化を, 表 7 としてネットワーク全体における自動車の現行 での平均遅れ時間，停止時間，停止回数を示しそれ ぞれの信号方式における改善率をまとめた.

表- 6 方向別遅れ時間の変化

\begin{tabular}{|c|c|c|c|c|}
\hline & \multicolumn{4}{|c|}{ 自動車 } \\
\hline \hline 方向 & $\mathrm{A}$ & $\mathrm{B}$ & $\mathrm{C}$ & $\mathrm{D}$ \\
\hline 淮優先信号 & $35.10 \%$ & $9.67 \%$ & $-10.21 \%$ & $-41.92 \%$ \\
\hline 優先信号 & $54.36 \%$ & $21.32 \%$ & $-83.21 \%$ & $-174.38 \%$ \\
\hline
\end{tabular}

表 -7 遅れ時間の比較

\begin{tabular}{|c|c|c|c|}
\hline 自動車 & 遅れ時間 & 停止時間 & 停止回数 \\
\hline 現行（秒） & 252 & 177.8 & 5.2 \\
\hline 潐優先信号 & $13.49 \%$ & $16.37 \%$ & $7.88 \%$ \\
\hline 優先信号 & $-25.75 \%$ & $-28.36 \%$ & $-17.50 \%$ \\
\hline
\end{tabular}

表 6 から優先信号方式, 準優先信号方式において
ション上での同一区間の旅行時間を $T_{i}^{\prime}$ とする. こ の結果と標準旅行時間とのずれ時間である $\left|T_{i}-T_{i}\right|$ の最大值および最小值を表 8 にまとめ, 図 14 としてずれ時間の例をあげる.

広島における路面電車の問題として速達性のほか に定時性の確保がある．道路に余裕のない都心での 路面電車の定時性確保のためには，電停等での時間 待ちが出来ないため, 信号のサイクル長やオフセッ トなどの影響に大きく依存してくる．現状の信号方 式と提案した信号方式のそれぞれにおいて時刻表と 比較してどの程度時間通りに電停に到着したかを評 価するために式 3 を用いる.この指標を八丁佣交差 点から紙屋町西電停下りにおいて用い, 路面電車到 着時間の定時性の評価を行った.

$$
\Delta T=\frac{\sum_{i=1}^{n}\left|T_{i}-T_{i}\right|}{n}
$$

ここに八丁堀電停から紙屋町西電停における路面電 車 $i$ の時刻上での標準旅行時間を $T_{i}$, シミュレー

表-8 紙屋町西電停でのずれ時間 (単位 : 秒)

\begin{tabular}{|c|c|c|c|}
\cline { 2 - 4 } \multicolumn{1}{c|}{} & 現行 & 準優先 & 優先 \\
\hline$\Delta \mathrm{T}$ & 108.13 & 132.96 & 101.35 \\
\hline 最大 & 330.2 & 322.6 & 312.1 \\
\hline 最小 & 12.3 & 12.7 & 3.5 \\
\hline
\end{tabular}

この結果 $\Delta T$ が最小となる信号方式は優先信号方 
式であり，現行の信号方式と比較しても改善される ことが分かる.

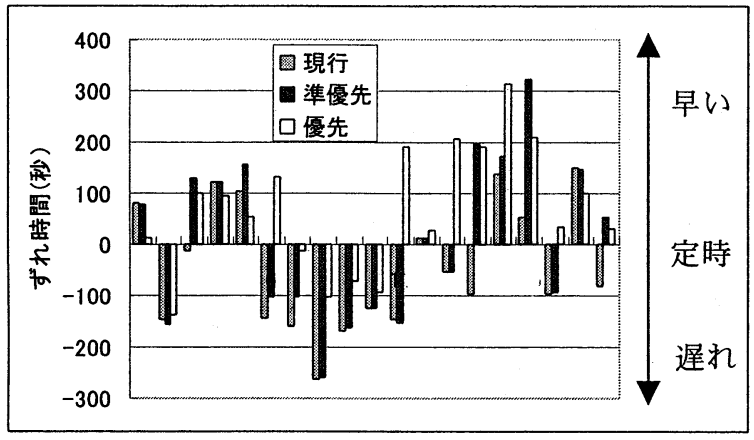

図-14 紙屋町西電停における到着ずれ時間の例

\section{（c）環境負荷の評価}

作成したネットワーク内での現行の信号方式と比 較した $\mathrm{NOx}$ よび $\mathrm{C} \mathrm{O}_{2}$ の総排出量の変化を表 9 に 示す.

\begin{tabular}{|c|c|c|}
\hline 9 & $x, c$ & 北車 \\
\hline & C02 改善率 & N0x 改善率 \\
\hline 準優先信号 & $12.26 \%$ & $5.71 \%$ \\
\hline 優先信号 & $-10.26 \%$ & $-8.43 \%$ \\
\hline
\end{tabular}

表 9 にあるように準優先信号方式では, 現行の信 号方式より環境に優しい信号方式であると考えられ る.

\section{（d）まとめ}

これらの結果から,交通負荷に関しては準優先信 号方式では現行の信号方式より路面電車, 自動車共 にネットワーク全体での交通負荷は改善される.ま た路面電車の速達性の向上も見込まれる. 一方で優 先信号方式では路面電車にとっては非常に有効な信 号方式であり速達性および定時性は向上するが, 南 北方向の自動車交通に与える影響が大きく，ネット ワーク全体で考えると混雑が悪化することが分かっ た.

本研究においては路面電車に対し有効な信号方式 としては優先信号方式である. 一方で準優先信号方 式は一部の自動車交通に支障がでるが，自動車の交 通負荷, 環境負荷および路面電車の運行状況におい て優れた信号方式と言える.これらを総合して該当 地域においては, 路面電車の運行状況の改善が見込
まれ，更には自動車の交通負荷，環境負荷に優れて いる準優先信号方式を用いることが有効であると考 えられる。

\section{7.おわりに}

国内の信号制御の研究は自動車交通に主眼を置き 渋滞緩和を目的としたものが主流である．しかし海 外では都市内にLRTが走る都市も多い．また国内で も広島市, 高知市など市内に路面電車が走る都市も 複数存在する.これらの都市における交通施策とし て路面電車を含めた信号方式に関する研究もこれか らは必要である.

本研究では, 広島市内の紙屋町交差点およびその 周辺域を対象に路面電車優先の信号制御方法を考案 し，交通シミュレータを用いた計算機実験を行いそ の有効性を示した．今後はさらに自動車交通を犠牲 にしない有効な路面電車優先信号方式のアルゴリズ ムの考案や, 感知器の設置位置の検討などを行う必 要がある．またネットワークを広げ複数交差点での 更に系統だった信号制御について評価できるよう発 展させていきたい．最後に自動車交通と路面電車交 通のトレードオフの関係を論理的に考察して行くこ とが必要である.

\section{謝辞}

最後に本研究を行うに際し,広島県警, 広島電鉄, 路面電車を考える会の方々に資料の提供,ご助言等 多大な協力を得ました。 また東京大学桑原教授, 東 京都立大学大口助教授, 名古屋大学加藤助教授, 慶 應高校坪田教諭, 広島電鉄中尾氏をはじめ, 多くの 方から貴重なご意見を頂戴しました。ここに，あら ためて感謝の意を表します。

\section{参考文献}

1)運輸省 :「平成 12 年度運輸白書」, 2000.

2)森津秀夫, 木村文彦, 大江洋史, 飯田祐三, 野寺 寿雄, 高木真志, 森山敏夫 : 「 L R T 導入に伴う 交通計画再検討ツールの開発」, 土木計画学研

究・論文集, Vol.18, No. 4, pp. 763-772, 2001.

3)中川大, 松中亮治, 芦澤宗治, 青山吉隆 : 「都市 
交通シミュレーションを用いたパッケージ施策の 便益に関する研究」, 都市計画学会学術研究論文 集, No36, pp. 583-588, 2001.

4) 山口耕平, 青山吉隆, 中川大, 松中亮治, 西尾健 司「ライフサイクル環境負荷を考慮した L R T 整 備の評価に関する研究」, 土木計画学研究・論文 集, Vol.18, No. 4, pp.603-610, 2001.

5)伊藤雅, 中川大, 西尾健司「公共交通と自動車交 通を統合した都市交通シミュレーションシステム を用いた L R T 導入効果の定量的検討」，土木学 会年次学術講演会講演概要集 第4 部, Vol. 54,pp. 2 72-273, 1999.

6)青柳篤, 森本章倫, 古池弘隆 :「S P 調查を用い た L R T 需要予測に関する研究」，第 31 回土木学 会関東支部技術研究発表会講演概要集CD-ROM, 200 3.

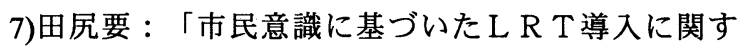
る基礎的検討 前橋市を事例に」，アーバンイン フラ・テクノロジー推進委員会会議技術発表会論 文集, Vol.13,pp. 111-116, 2002.

8)太田智, 中野雅弘, 大島秀樹 : 「都市交通として の L R V 導入に関する利用者意識の一考察」，土 木計画学研究・講演集, Vol. 26 Pt2, 2002.

9)奥村幾正, 渡辺俊勝, 水間毅 : 「 L R T 用信号シ ステムの交通流からのシミュレーションによる評 価」, 電気学会資料 交通・電気鉄道研究会, Vol. TER-00, pp. 27-32. 2000.

10 ) 水間毅, 加藤忠彦, 佐藤安弘, 白土義男：「電
車優先信号方式の実態と今後の方向」, 電気学会 資料 交通・電気鉄道研究会, Vol. TER-00, pp. 28-3 $4,2000$.

11)VISSIMホームページ : ht tp://wWw. english.ptv. de/cgi-bin/traffic/traf_vissim.pl

12) PTV AG : 「VISSIM Traffic flow Simulation Te chnical Description」,2001.

13) NGAN V : 「A Comprehensive Strategy for Tra nsit Signal Priority」, Inst Transp Eng, V 01. 73, No. 11, pp. 28-32, 2003.

14）広島電鉄電車カンパニー企画チーム：「乗降客 実態調查」, 2000.

15) 東京都環境保全局：「都内自動車走行量及び自 動車排出ガス量算出調査報告書」, 1997.

16) 熊谷 英治, 森 俊介：「首都圈広域ネットワー クにおける動的制御最適化モデルの構築と環境影 響評価」，エネルギーシステム・経済環境コンフ アレンス講演集, 2001.

17) 藤井聡, 菊地輝, 北村隆一：「マイクロシミュ レーションによる $\mathrm{CO}_{2}$ 削減に向けた交通施策の検 討 : 京都市の事例」, 交通工学, Vol.35, No.4, pp. $11-18,2000$.

路面電車を考慮した都市交通における信号方式に関する研究

松本 修一・熊谷 靖彦・川嶋 弘尚 本研究では路面電車の交通状況の改善およびそれに伴う自動車の交通状况の変化に関して, 路面電車優先信号 方式を提案した. その結果計算機実験において路面電車の速澾性，定時性，それに伴う自動車交通の変化，環境 負荷の観点から評価を行った. その結果研究対象ネットワーク全体として路面電車および自動車の交通状况，そ れに伴う環境負荷の軽減される信号方式の可能性が示唆される. 


\section{A Study on the Traffic Signal Strategy in City Traffic Consideration of Streetcar Shuichi MATSUMOTO, Yasuhiko KUMAGAI, Hironao KAWASHIMA}

In this study, the streetcar priority signaling strategies are considered in conjunction with improvements of the traffic situation of streetcars, and the traffic situation of vehicles related to the movement of the streetcars. In the computer experience, various strategies are evaluated in terms of environmental load by considering the speed and the punctuality of streetcars, and the road traffic situation influenced by the movement of streetcars. As a result, this paper shows the possibility of the traffic signal strategy which mitigates the situations of streetcar and surrounding vehicles such that the environmental load is minimized. 